\title{
A Cross-Disciplinary Narrative Approach of Sandplay in Preschool Education
}

Rada Pura, Mușata Bocoș 


\title{
A Cross-Disciplinary Narrative Approach of Sandplay in Preschool Education
}

\author{
Rada Pura ${ }^{a *}$, Mușata Bocoṣ ${ }^{b}$ \\ ${ }^{a}$ Tyrihans Barnehage kindergarten, 7 A Dalsetveien Street, Stavanger, 4018, Norway \\ ${ }^{b}$ Faculty of Psychology and Educational Sciences, Babeș-Bolyai University, 7 Sindicatelor Street, Cluj-Napoca, 400029, Romania
}

*Corresponding author: rada.beatrice@yahoo.com

\section{Abstract}

Keywords: narrative, Sandplay Therapy, ludic approach, zone of proximal development (ZPD)

\section{Zusammenfasung}

Schlüsselworte: Erzählung,

Sandspieltherapie, Sandspiel in der Vorschulerziehung, Zone der proximalen Entwicklung (ZPD)
Narrative is central for human beings and it is an instrument for organizing our entire experience. Personal, familial, organizational and national identity is being shaped by the narrative. It gives meaning to the world around us. Play is a specific tool that can be used to straighten young children's narrative. A free, symbolic, creative play such as Sandplay can be adopted to maximize the opportunities of observing and sustaining preschoolers' narrative. Dora M. Kalff is the founder of Sandplay Therapy, being influenced by "The World Technique" of Margaret Lowenfeld but playing with sand has always been attractive both to children and adults. In preschool educational settings telling stories in the sand offers educators a way of extending children's narrative by using open questions, dialogues and by developing children's awareness that story fictional world can be enriched.

\section{Introduction}

The urge to tell stories, to express thoughts and feelings, verbally, visually or by using body language, has been defining the human being from ancient times. Today the oldest "story" ever told, lays on a stone fragment found in cave Blombos, in South Africa, dating year 75 $000 \mathrm{BP}$, the artwork was created in ochre using the crosshatching technique.

In its primordial and instinctual form, the narrative, a social and affective phenomenon, is a resource for making ourselves known and for getting to know others. It's sculpting our human identity at a personal, familial, organizational, or national level, giving meaning to the world around us. The narrative defines the human being and it's a tool for organizing its entire experience.

The narrative implies any way of expressing (verbally, visually, or by body language) as well as the narrative context, defined by the complex interaction provided by answers to questions like Who? When? Where? Why? How? What? etc. "Note one further thing about narrative 'allure. Stories, again unlike logical propositions, cannot be context-free, cannot live in a vacuum. Even when a story is intended only as a fable, it is always located in a cultural setting [...] To borrow Claude Levi Strauss's apt definition, culture is comprised of the ordinary ways and means by which we routinely and without much quarrel carry out our exchanges with each other, whether the exchange of good, services, respect, affiliation, whatever" (Bruner, 2010, p. 40).

The term narrative is currently being used within a multitude of fields such as literature, psychology, sociology, pedagogy, history, politics, cinematography, fine and digital arts and lately in computer games or even industrial fields, using, for instance, $3 \mathrm{~d}$ animation to explain products and technologies. The wide spreading of the term, outside of the literature framework and, into multiple other fields, has flattened its meaning, while at the same time, paradoxically, it has enhanced it, adapting entirely to all contexts so that "the term has come to mean anything and everything" (Riessman, Speedy, 2007, p.428 apud Sørly, Blix, 2017, p. 47).

"There are countless forms of narrative in the world. [...] Among the vehicles of narrative are articulated 
language, whether oral or written, pictures, still or moving gestures, and an ordered mixture of all those substances; narrative is present in myth, legend, fables, tales, short stories, epics, history, tragedy, drama [suspense drama], comedy, pantomime, paintings (in Santa Ursula by Carpaccio, for instance), stained-glass windows, movies, local news, conversation. [...] Like life itself, it is there, international, transhistorical, transcultural" (Barthes, Duisit, 1975, p. 237 apud Sørly, Blix, 2017, p. 26).

Same way as the symbols in dancing form a narrative path, or as admiring a painting inspires a whole interior monolog, sand play, on a beach or in an established pedagogical/therapeutic environment, encloses a story told by the one playing, a part of her/his identity. Studies consider that narrative is very important in shaping children's identity, starting from a very early age. "The way in which they conceive of a story is critical in determining how they generate and organize their entire narratives [...] To the young child, a story may be any piece of important topic the child wants to talk about" (Bamberg, 2010, p. 17).

Playing is a specific method of organizing young children's narrative. The adult becomes a partner who has the role of containing and sustaining the child's effort to make sense of reality. Playing is an interpretation of the narrative, in which a "fictional pact" (Umberto Eco) is made between the partners.

The ludic approach is used as an instrument that maximizes the possibilities of observing and sustaining preschoolers' narrative, accessing the zone of proximal development (ZPD).

In this article, we'll distinguish between Sandplay - as a therapy method and Sandplay in Preschool Education as a didactic instrument.

\section{Theoretical background of the term narrative}

The pioneers of narrative theory, starting with Plato (third Book of the Republic) and Aristotle (Poetics) and even Claude-Levi Strauss, T. Todorov, U. Eco, Vladimir Propp, etc. were preoccupied with the study of narrative regarding literary genres, Vladimir Propp laying the foundation of modern narratology with his book Morphology of the tale (1928). Roland Barthes and Claude Bremond have raised the term narrative to the status of a "semiotic phenomenon that transcends disciplines and media" (Routledge Encyclopedia of Narrative Theory, 2005, p. 470).

Routledge Encyclopedia of Narrative Theory, published for the first time in 2005, highlights the fact that in the last decades, there has been a distinct increase in the interest granted to the narrative term, which has gradually come to the attention of many different fields of human knowledge.

In more recent studies and conferences (The International Society for the Study of Narrative (ISSN) with its annual conferences, of which the first conference took place in 1986 at Ohio State University), people from different domains that are preoccupied with the potential of narrative theory, try to find common ground (http://narrative.georgetown.edu/).

According to the Routledge Encyclopedia of Narrative Theory, the narrative term generally supports two explanatory tendencies, with some authors trying to define the term, and others trying to describe it instead. The descriptive tendency is generally consistent, the descriptions written by different authors completing each other: "narrative is a fundamental way of organizing human experience and a tool for constructing models of reality (Herman, 2002); [...] narrative is a particular mode of thinking, the mode that relates to the concrete and particular as opposed to the abstract and general (Bruner, who distinguishes 'narrative' and 'scientific' thinking); [...] narrative is a mold in which we shape and preserve memories; narrative, in its fictional form, widens our mental universe beyond the actual and the familiar and provides a playfield for thought experiments (Schaeffer, 1999)" etc. (Routledge Encyclopedia of Narrative Theory, 2005, p. 471). Bruner also states that "Narrative is rather an all-purpose vehicle. It not only shapes our ways of communicating with each other and our ways of experiencing the world, but it also gives form to what we imagine, to our sense of what is possible" (Bruner, 2010, p. 39). Deborah Schiffrin and Anna de Fina capture in an artistic manner, a complex and general sense of the narrative term while writing the introduction to Telling Stories, Language, Narrative, and Social Life (2010): "Narratives are fundamental to our life. We dream, plan, complain, endorse, entertain, teach, learn and reminisce by telling stories. They provide hopes, enhance or mitigate disappointments challenge or support moral order, and test out theories of the world at both personal and communal levels" (Schiffrin, De Fina, 2010, p. 1).

In contrast, the tendency which aims to define the term is characterized by many disagreements. "A narrative is a story that tells a sequence of events that are significant for the narrator and his or her audience. A narrative as a story has a plot, a beginning, a middle and an end. It has an internal logic that makes sense to the narrator. A narrative relates events in a temporal, causal sequence" (Herman, 2002 apud Routledge Encyclopedia of Narrative Theory, p. 471). J.A. Holstein and J.F. Gubrium connect the narrative term to the historical, institutional and interpersonal context, C.K. Riessman wishes to emphasize the existence of a clear distinction between the narrative 
term and storytelling, but the same author returns to this difference in more recent works (2008) overlapping the two terms, E.G. Mishler considers that the narrative term has psychological, social and cultural functions (Sørly, Blix, 2017).

The complexity of the narrative term has determined, depending on the approach and the field in which it was defined or described, an exceptional derivation, generating a multitude of related terms, such as small stories (Bamberg, 2007) - an umbrella term for stories, past, ongoing, future, hypothetical or imagined events, but also discussions, letters, etc.; big stories (Bamberg, 2007) memoirs, autobiographies, life stories, etc.; embodied narrative - The Theory of Embodied Cognition; mental mapping of narrative - inspired by cognitive linguistics and cognitive psychology, etc. (Routledge Encyclopedia of Narrative Theory, 2005).

To illustrate the exceptional derivation of the term, it is sufficient to mention some of the entries in the Routledge Encyclopedia of Narrative Theory (2005): artificial intelligence and narrative, atomic and molecular narratives, biblical narrative, cognitive narratology, computer games and narrative, courtroom narrative, dance and narrative, digital narrative, drama and narrative, dream narrative, education and narrative, emotion and narrative, ethnographic approaches to narrative, film narrative, Holocaust narrative, identity and narrative, image and narrative, institutional narrative, media and narrative, medicine and narrative, medieval narrative, music and narrative, narrative as a cognitive instrument, narrative games and play, narrative in poetry, narrative intelligence, narrative semantics, narrative structure, narrative therapy, oral cultures and narrative, prison narrative, science and narrative, sociolinguistic and narrative, travel narrative, visual narrativity, etc.

We consider that the term narrative is relevant regarding preschool education from a linguistic and psycho-pedagogical perspective. Narrative shapes children's identity develops their vocabulary and, it offers us, educators, a precious tool in supporting the focus on the zone of proximal development (ZPD) and in forming strong, close and healthy relationships with the children. Sandplay (playing is regarded as an organizer of the narrative in preschoolers) has the potential to become such an instrument because it meets the necessary conditions to provide an organized observational framework. This type of play does not limit the manifestation of creativity and the psychic of the preschooler. It involves non-intrusive adult interventions, aimed towards achieving pedagogical objectives.

\section{Sandplay - the educational versus therapeutic approach}

The first to use Sandplay as a therapeutic technique was Margaret Lowenfeld, inspired, by H.G. Wells' book Floor Games. Lowenfeld called this technique "The World Technique" and found that this technique helped children to manifest their feelings and emotions without the need of an adult intervention (Zoja, 2013).

"The World Technique" will influence Dora M. Kalff, a Jungian therapist, to create the therapeutic method known today as Sandplay. She described the processes involved in working with this method from the perspective of analytical psychology, receiving Jung's support. The Sandplay therapeutic method was first described in 1966 in an article entitled The archetype as a healing factor.

"Sandplay therapy is a therapeutic method developed to provide a means of helping children with mental suffering. It is non-verbal play therapy that intentionally creates a space for the unconscious to manifest [...] Sandplay is now used with adult clients as well. The Sandplay method consists of the psychotherapy client's creation of a three-dimensional picture using miniature figures in a tray of sand" (Turner, 2017, p. 1).

This method of therapy requires that the space in which the psychotherapist operates is equipped with two boxes of sand (approx. 50/70/10 cm.), one for the use of dry sand and the other for wet sand, as well as a generous collection of miniatures (small collections containing up to 200-300 figurines, the bigger ones adding up to several thousand).

Starting from the basic Sandplay technique, several new approaches have been developed over time. In Romania, there is the Romanian Association for Sandplay Therapy, endorsed by the Romanian College of Psychologists and affiliated with the International Association for Sandplay Therapy. Since 2018, it offers continuing educational training, accredited by the Ministry of Education.

Next, we will distinguish between Sandplay Therapy, and Sandplay in Preschool Education to distance ourselves from the therapeutic method. We also do not want Sandplay in Preschool Education to be confused with playing in the sandpit or with playing in the Sand and Water Centre/Area. However, the therapeutic function of play and the therapeutic function of Sandplay is not disregarded.

Sandplay Therapy has been adapted to the educational framework by Kristin Unnsteinsdottir (Iceland), a psychopedagogue and a Sandplay therapist at the Artúnsskóli Learning Center in Reykjavik. She used it as a therapy method and initiated a recovery program for primary school children struggling with different learning, emotional and behavioral difficulties. Her observations 
have been included in her doctoral thesis as well as the book Sandtray Play in Education: A teacher's Guide (2015), which she co-authored with Barbara Turner, a former student of Dora Kalff and the founder of Association for Sandplay Therapy.

Sand, water and even mud are very attractive playing materials for preschoolers. These are the most natural play materials one can think of and are very easy to find. In our pedagogical practice, we have used Sandplay with preschoolers in different pedagogical and didactic situations, this instrument is characterized by great flexibility.

It has been proven useful in a social-emotional development program, conducted over a school year. The participants were given the possibility to create different scenarios, stories or situations which allow greater visibility to the relationships between children, in an organized framework, using concrete data collection tools.

Sandplay has supported our pedagogical efforts during the children's adaptation period from the beginning of the school year, the potential of this type of play being fully used in creating feelings of confidence and emotional safety in a very short period.

Using concrete objects (miniatures and small toys), Sandplay is a valuable tool for preschool educators because it facilitates the dramatization of stories, helps children in retelling stories, allows them to create their own stories and it supports the complex mechanisms involved in the process of memorization. Preschool children learn faster and better if a text is accompanied by images, but they learn even faster and better if they are given objects that duplicate the concrete nouns of the text (characters and objects from a story/fairytale).

Regarding the involvement of shy, anxious or insecure children in different activities, Sandplay proved to be a very valuable pedagogical tool.

\section{Narrative perspective of Sandplay in Preschool Education. Didactic approaches}

The performing perspective on the narrative includes also physical movement, culture, and socialization in the definition of the term. This means people's stories are seen as "a bodily communicative event and activity that involves other - embodied - persons and the social and cultural situation" (Hydén, 2013, p. 235 apud Sørly, Blix, 2017 , p. 55). The narrative involves the body with its senses, gestures, movements, as well as other people. It is something that the human being not only thinks or says but also something that produces through body language (Sørly, Blix, 2017). The narrative of a person is interlaced with the narrative of people with whom he or she communicates. This highlights the importance of the mirror neurons' role (Rizzolatti, Fadiga, Gallese \& Fogassi, 1996) and peripersonal space (Iacoboni, 2008).

These concepts are relevant to educators in general, but also particularly concerning Sandplay in Preschool Education. Mirror neurons are responsible for simulating the virtual reality of another person's actions, a simulation that helps us understand the behavior and emotions of other people, as well as to have insight into other people's actions and be capable of empathy.

When it comes to Sandplay in Preschool Education, the adult uses his words, his body posture, gestures, mimic, and paralanguage to make the child feel accepted and appreciated. The image created by the child in the sandbox is very valuable and the educator must mirror the child's emotions and feelings. Sandplay in Preschool Education is not something that can be evaluated as correct or incorrect and does not require that children possess any specific skills, it is something every child can do. The feelings of confidence, emotional safety, high self-esteem that are developed through this type of play lead to creating a state of mind that is favorable to learning. The miniatures used, the image in the sand, the adult, in other words, everything that is included in the peripersonal space of the child is integrated into his or her neural maps (Turner, Unnsteinsdottir, 2011). This is important also for educators not only for therapists.

In the interpretation of the visual narrative, of the final product, not only the symbolism of the used objects and the overall image is important to take into account, but also the process that leads to the final product and the relationship between adult and child. In our vision, Sandplay with miniatures in preschoolers is multidimensional and can be analyzed and made use of on many different plans that complement each other:

- the concrete plan (actions and dialogues)

- the symbolic plan (miniatures and the different ways of using the sand)

- the therapeutic plan (emotions, feelings, and desires)

- the pedagogical plan (the different goals that the educator sets)

- the narrative plan (organization/ interpretation/ dramatization of the narrative)

- the relationships plan (child-adult relationships; childchild relationships)

- the potential plan (D.W. Winnicott - potential space).

Regardless if it's about memorization, retelling or creating a story, common dialogues and interactions, the adult influences the organizing of a child's narrative. In this regard is important to consider narrative as a tool for shaping identity but also a tool for language development. 
It is well known that learning is facilitated by engaging children in play and storytelling but children need guidance in this regard.

Unnsteinsdottir (2011) discovered that stories created by children are similar in many ways to the traditional stories. She paraphrased Max Lüthi, saying that he observed that the traditional stories have only one dimension, in which the real world merges with the magic world, characters miss the biographical and psychological depth and motivation, the realistic details are most often absent, there is a tendency towards extremes and strong contrasts, they contain fixed formulas and the relationships between characters lack complexity and duration.

When children retell a story or they create one, they often drift away offering a perfect opportunity for the adult to approach the situation by helping the children to "fill in the gaps" as Umberto Eco said... "For the moment, let us note that any narrative fiction is necessarily and fatally swift because in building a world that comprises myriad events and characters, it can not say everything about this world. It hints at it and then asks the reader to fill in a whole series of gaps" (Eco, 1997, p. 2). Characters can receive a short autobiography, motives can be found for their behaviors, "the gaps" of the text can be filled by applying a narrative approach to Sandplay. Children create in the real world, with their own hands, the fictional environment of the story. They give the characters a chance to interact in the real world, by positioning and manipulating them and they also imprint onto this "new world", a part of their psychic. In other words, they reinvent the story, creating a narrative circuit extremely valuable from a pedagogical, psychological and linguistic point of view.

The adult's role is to sustain this effort and to help children explore the text's elasticity or extend the narrative. By extending the narrative, we understand, not only enriching children's descriptive vocabulary, but also developing the children's awareness that the characters can be invested with emotions and feelings, with more characteristics, and that their actions are triggered by a reason, etc.

The extending of the narrative is achieved based on the story illustrated in the sand, by asking open questions to the children, by building on the clues they give us, exploring the latent content of the story. Knowledge, thoughts, and emotions are visually transferred into the sand, while at the same time the educator develops a culture of listening pedagogy (Reggio Emilia). What do children really talk about? What are they thinking about? How can children be engaged in extended dialogs and how can the efficiency of these dialogs be evaluated?
Sandplay in Preschool Education can be used to develop individual learning paths, focused on the child's interests and needs. Children are more interested in something they have built themselves. Creating a story using sand and miniatures makes them more receptive to new information. It's known that in preschool, a child can learn almost anything through stories, even, for instance, decomposition of number five, especially if it's illustrated in the sand using five cute little mice that try to, one by one, cross on the other side of a fence.

Conversations between adults and children can facilitate reaching many subjects, highlighting the children's interests and also offering a cognitive challenge, the adult's suggestions can encourage exploration of new possibilities other than the obvious ones.

Aside from the pedagogical goals, the educator must oversee other aspects of Sandplay, that might offer additional information about the child: the theme illustrated in the sand, the level of child's confidence, the child's relationship with the sand, the miniatures, with the other children and the adult. More information can be found in the miniatures symbolism, the content of the tray, and the quality of the dialogs and nonverbal language.

The thematic analysis of the stories illustrated in the sand and the analysis of the psycho-pedagogical process that went on in Sandplay is extremely significant.

\section{Conclusions}

Sandplay in Preschool Education has important benefits: it is a wonderful tool for shaping the children's narrative, develops language, encourages problemsolving, stimulates imagination and creativity, develops fine motor skills, promotes a state of relaxation and brings to surface (in a safe manner) the negative emotions children might have experienced at some point.

From a cross-disciplinary narrative perspective, Sandplay in Preschool Education is a useful didactical and psycho-pedagogical tool. This kind of play helps shape the children's narrative from a cognitive and affectionate point of view. Storytelling in the sand helps build strong social bridges between adults and children and amongst children. "The «truth» or «accuracy» of narratives takes a back seat to what is socially accomplished through storytelling" (Holstein, Gubrium, 2012, apud Sørly, Blix, 2017 , p. 113). Regardless if we call it Sandplay in Preschool Education or storytelling in the sand, this kind of playing offers us a glimpse into the rich inner world of young children.

\section{Author note:}


The authors have equal contributions to this article.

Rada Pura is currently a pedagogical leader at Tyrihans Barnehage, in Stavanger, Norway. She graduated from the Faculty of Psychology and Educational Sciences and has two Master's degrees in the field of Educational Science, specialization: School counselling and psychopedagogical assistance, and Instructional designer. Her research is in the field of social-emotional education, ludic approaches in preschool education, storytelling, and innovation in preschool education. She is also interested in finding creative techniques in teaching a second language to young learners (Primary Essentials Teacher Training Course, British Council) and in Sandplay Therapy (Sandplay Integrativ Practitioner, Romanian Association for Sandplay Therapy).

Mușata Bocoş is University Professor and Ph.D. Coordinator at the Faculty of Psychology and Sciences of Education (Babeș-Bolyai University, Cluj-Napoca, Romania). She has obtained a Ph.D. in Educational Sciences in 1997 at Babeș-Bolyai University. Her research interests are reflected in a series of studies and articles published in important national and international journals. Her teaching activity covers several domains such as the theory and methodology of curriculum, general didactics, and educational research.

\section{References}

Bamberg, M. (Ed.) (2007). Narrative - State of the Art. Amsterdam/Philadelphia: John Benjamins Publishing.

Bamberg, M. (2010). Narrative Development: Six Approaches. New York: Routledge, Taylor \& Francis Group.

Barthes, R., Duisit, L. (1975). An Introduction to the Structural Analysis of Narrative. New Literary History, Vol.6, Issue 2, p. 237-272.

Bruner, J. (2010). Narrative, culture, and Mind. In Telling Stories Language, Narrative, and Social life, edited by D. Schiffrin, A. De Fina, and A., Nylund, 45-50, Washington, DC: Georgetown University Press.

Eco, U. (1997). Six Walks in the Fictional Woods. Cambridge, Massachusetts and London, England: Harvard University Press.

Herman, D. (2002). Story Logic: Problems and Possibilities of Narrative. Lincoln: University of Nebraska Press.

Holstein, J.A., Gubrium, J.F. (2012). Introduction: Establishing a balance. In Holstein, J.A., Gubrium, J.F. (eds.). Varieties of Narrative Analysis. Thousand Oaks, CA: SAGE Publications.
Hydén, L.-C. (2013). Towards an embodied theory of narrative and storytelling. In Hatavara, M., Hydén, L.-C. and Hyvärinen, M. (eds.). The Travelling Concepts of Narrative. Amsterdam/Philadelphia: John Benjamins Publishing Company.

Iacoboni, M. (2008), Mirroring People: The Science of Empathy and How We Connect with Others, $1^{\text {st }}$ Edition, New York: Farrar Straus Giroux.

Riessman, C.K., Speedy, J. (2007). Narrative Inquiry in the Psychotherapy Profession. A Critical Review. In Clandinin, D. J. (eds.). Handbook of Narrative Inquiry. Mapping a Methodology. Thousand Oaks, CA: SAGE Publications.

Rizzolatti, G., Fadiga, L. Gallese, V., Fogassi, L. (1996), Premotor cortex and the recognition of motor actions, in Cognitive Brain Research, Volume 3, Issue 2, March, pp. 131141 (https://doi.org/10.1016/0926-6410(95)00038-0).

Schiffrin, D., De Fina, A., Nylund, A. (2010). Telling Stories. Language, Narrative and Social Life. Washington, DC: Georgetown University Press.

Sørly, R., Blix, B.H. (2017). Fortelling of Forskning. Narrativ teori og metode i tverrfaglig perspektiv. Stamsund: Orkana Akademisk.

Turner, B.A. (Ed.) (2017). The Routledge International Handbook of Sandplay Therapy. New York: Routledge.

Turner, B.A., Unnsteinsdóttir, K. (2015). Sandtray play in Education. A teacher's Guide. Cloverdale: Temenos Press.

Turner, B.A., Unnsteinsdóttir, K. (2011). Sandplay and Storytelling: The Impact of Imaginative Thinking on Children's Learning and Development. Cloverdale: Temenos Press.

Zoja, P.E. (2013). Sandwork expresiv. O abordare jungiană. București: Editura Harald.

*** Routledge Encyclopedia of Narrative Theory (2005). London and New York: Taylor \& Francis Group. http://narrative.georgetown.edu/ (accessed at 29.03.2020). 